\title{
SPATIAL VARIABILITY OF VOLATILE ORGANIC COMPOUNDS IN STREAMS ON LONG ISLAND, NEW YORK, AND IN NEW JERSEY
}

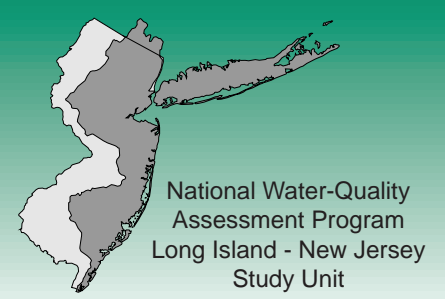

\section{Background}

Volatile organic compounds (VOCs) are found in almost all natural and synthetic materials and are commonly used in fuels, fuel additives, solvents, perfumes, flavor additives, and deodorants. Potential health hazards and environmental degradation resulting from the widespread use of VOCs has prompted increasing concern among scientists, industry, and the general public.

Initial interest in VOCs was related to their presence in the atmosphere. In the 1950 s it was discovered that the photooxidation of VOCs in the presence of nitrous oxides resulted in air pollution known as "smog" (Bloemen and Burn, 1993). Later, VOCs in the stratosphere were found to be related to ozone depletion over the Antarctic and to potential global climate change (Bloemen and Burn, 1993). VOCs introduced to the environment by large accidental spills of crude petroleum and fuel products and concentrated in industrial waste also received considerable attention (Schwarzenbach and others, 1993). More recently, however, interest in ambient levels of VOCs in air, soil, and natural waters has increased, partly as a result of unexplained locally elevated cancer rates and other health complaints. The relation between these reports and the presence of VOCs at low concentrations in the environment is an area of active debate and research.

One of the long-term goals of the U. S. Geological Survey's (USGS) National Water Quality Assessment (NAWQA) program is to document the presence and identify possible sources of contaminants in the Nation's water resources. The Long Island-New Jersey (LINJ) coastal drainages study is one of 59 planned investigations that constitute the NAWQA program. Because the LINJ study area is one of the most densely

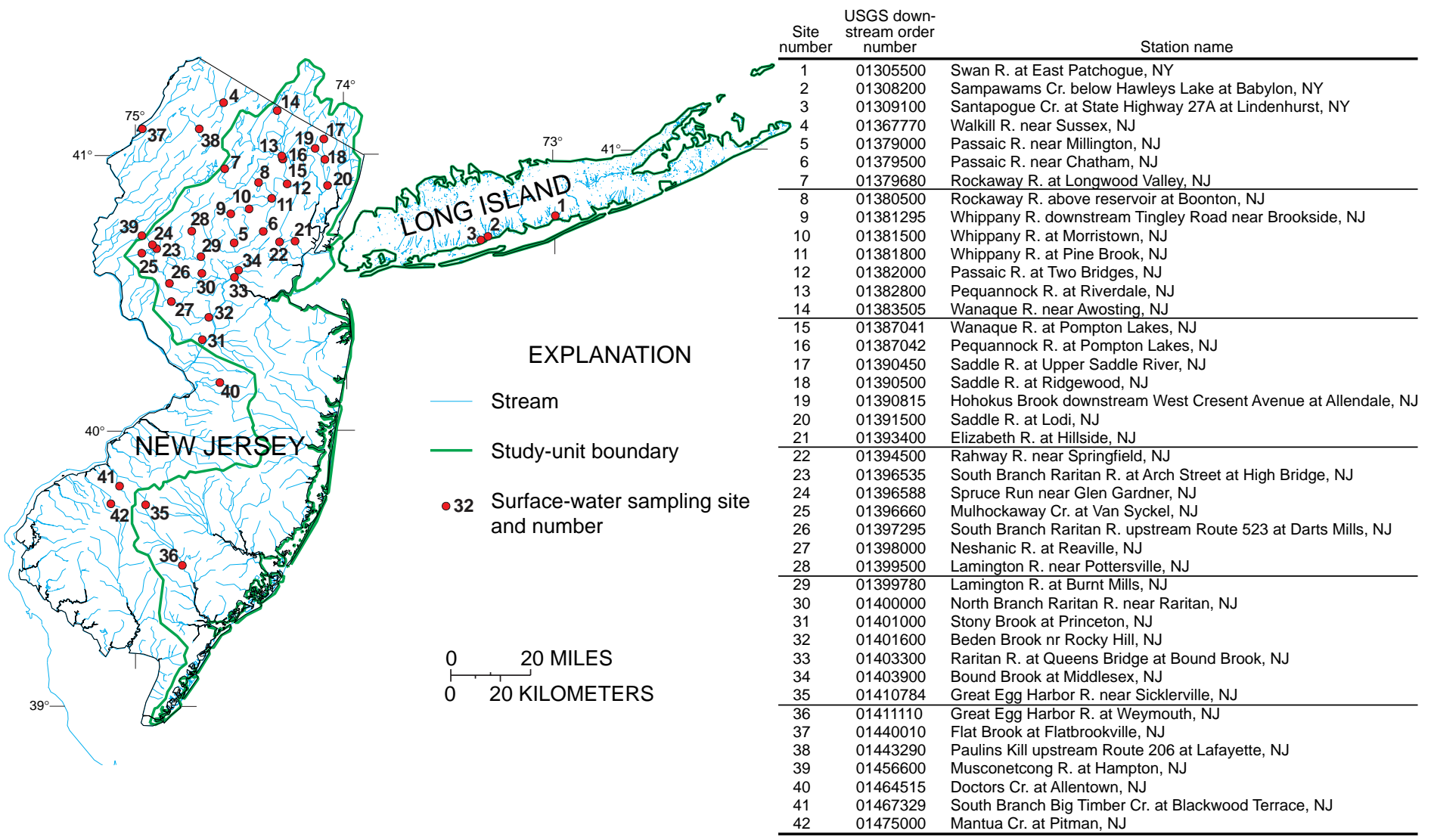

Figure 1. Locations of sampling sites and streams sampled for volatile organic compounds, January 27-30, 1997. 
Table 1. Volatile organic compounds detected in 42 surface-water samples collected from streams on Long Island, New York, and in New Jersey, January 27-30, 1997

[IUPAC, International Union of Pure and Applied Chemistry; NWQL, U.S. Geological Survey National Water Quality Laboratory; NDV, non-detect value; MCL, drinking-water maximum contaminant level (U.S. Environmental Protection Agency, 1996); HAL, health-advisory level, 70 kilogram adult, lifetime (U.S.Environmental Protection Agency, 1996); USEPA, United States freshwater water-quality chronic criteria (U.S. Environmental Protection Agency, 1995); CAN, Canadian freshwater water-quality criteria (Canadian Council of Resource and Environment Ministers, 1991; $\mu \mathrm{g} / \mathrm{L}$, micrograms per liter; --, criterion does not exist; E, Estimated value; N/A, not available]

\begin{tabular}{|c|c|c|c|c|c|c|c|c|}
\hline $\begin{array}{l}\text { Compound name } \\
\text { (IUPAC/NWQL) }\end{array}$ & Trade name & $\begin{array}{l}\mathrm{NDV} \\
(\mu \mathrm{g} / \mathrm{L})\end{array}$ & $\begin{array}{c}\text { Detection } \\
\text { frequency } \\
\text { in percent } \\
\text { (number of } \\
\text { samples) }\end{array}$ & $\begin{array}{c}\text { Median } \\
\text { concentra- } \\
\text { tion of all } \\
\text { detections } \\
(\mu \mathrm{g} / \mathrm{L})\end{array}$ & $\begin{array}{c}\text { Maximum } \\
\text { concentra- } \\
\text { tion of all } \\
\text { detections } \\
(\mu \mathrm{g} / \mathrm{L})\end{array}$ & $\begin{array}{c}\begin{array}{c}\text { Site of } \\
\text { maximum } \\
\text { concentration } \\
\text { (fig. 1) }\end{array} \\
\text {. }\end{array}$ & $\begin{array}{c}\text { MCL or HAL } \\
(\mu \mathrm{g} / \mathrm{L})\end{array}$ & $\begin{array}{l}\text { Freshwater chronic } \\
\text { criteria for aquatic life } \\
(\mu \mathrm{g} / \mathrm{L})\end{array}$ \\
\hline Methyl tert-butyl ether/Methyl-t-butyl ether & MTBE & 0.10 & $100(42)$ & 0.36 & 8.7 & 01309100 & HAL $20-200$ & -- \\
\hline Acetone & Acetone & 5.00 & $64(27)$ & E2.6 & 6.6 & 01393400 & -- & -- \\
\hline Naphthalene & Naphthalene & 0.20 & $55(23)$ & E0.02 & 0.68 & 01393400 & HAL 20 & USEPA 620 \\
\hline Tetrachloroethene & Perchloroethene, PCE & 0.05 & $55(23)$ & E0.03 & 4.6 & 01308200 & MCL 5.0 & CAN 110 \\
\hline Trichloromethane/Chloroform & Chloroform & 0.05 & $55(23)$ & E0.03 & 0.10 & 01393400 & MCL 100 & CAN 2, USEPA 1,240 \\
\hline Trichloroethene & TCE & 0.05 & $50(21)$ & 0.08 & 1.2 & 01309100 & MCL 5.0 & CAN 20, USEPA 21,900 \\
\hline 1,1,1-Trichloroethane & Methylchloroform & 0.05 & $43(18)$ & $\mathrm{E} 0.02$ & 0.92 & 01309100 & MCL 200 & -- \\
\hline cis-1,2-Dichloroethene & (z)-1,2-Dichloroethene & 0.05 & $41(17)$ & E0.05 & 0.90 & 01309100 & MCL 70 & -- \\
\hline Methylbenzene/Toluene & Toluene & 0.05 & $41(17)$ & E0.03 & 0.24 & 01393400 & MCL 1,000 & CAN 2 \\
\hline 1,3 and 1,4-Dimethylbenzene $/ m$ and $p$-Xylene & meta and para-Xylene & 0.05 & $26(11)$ & E0.02 & 0.20 & 01393400 & MCL 10,000 & -- \\
\hline Diethyl ether & Diethyl ether & 0.10 & $26(11)$ & E0.1 & 0.15 & 01387041 & -- & -- \\
\hline tert-Amyl methyl ether & TAME & 0.10 & $26(11)$ & E0.02 & 0.08 & 01309100 & -- & -- \\
\hline Carbon disulfide & Carbon disulfide & 0.05 & $24(10)$ & E0.01 & 0.02 & 01309100 & -- & -- \\
\hline 2-Butanone/Methylethyl ketone & Methylethyl ketone & 5.00 & $21(9)$ & E0.5 & 2.0 & 01391500 & -- & -- \\
\hline 1,2,4-Trimethylbenzene & Psudocumene & 0.05 & $17(7)$ & E0.02 & 0.42 & 01393400 & -- & -- \\
\hline 1,4-Dichlorobenzene & $p$-Dichlorobenzene, 1,4-DCB & 0.05 & $17(7)$ & E0.01 & 0.09 & 01309100 & MCL 75 & CAN 4.0 \\
\hline 1,1-Dichloroethane & Ethylidene dichloride & 0.05 & $14(6)$ & 0.14 & 0.81 & 01308200 & - & -- \\
\hline Benzene & Benzene & 0.05 & $14(6)$ & E0.04 & 0.10 & 01393400 & MCL 5.0 & CAN 300 \\
\hline 1,2-Dichlorobenzene & $o$-Dichlorobenzene, 1,2-DCB & 0.05 & $12(5)$ & 0.09 & 0.18 & 01308200 & MCL 600 & CAN 2.5, USEPA 763 \\
\hline 1,2-Dimethylbenzene/o-Xylene & $o$-Xylene & 0.05 & $12(5)$ & E0.03 & 0.10 & 01393400 & MCL 10,000 & -- \\
\hline Chlorobenzene & Monochlorobenzene & 0.05 & $12(5)$ & E0.04 & 0.10 & 01403900 & MCL 100 & CAN 15, USEPA 50 \\
\hline Ethylbenzene & Phenylethane & 0.05 & $12(5)$ & E0.01 & 0.06 & 01393400 & MCL 700 & CAN 90 \\
\hline 1,1-Dichloroethene & Vinylidene chloride & 0.10 & $10(4)$ & 0.15 & 0.32 & 01309100 & MCL7.0 & -- \\
\hline 4-Methyl-2-pentanone/Methyl isobutyl ketone & Methyl isobutyl ketone & 5.00 & $10(4)$ & E0.1 & 0.4 & 01308200 & - & -- \\
\hline 1,3-Dichlorobenzene & $m$-Dichlorobenzene & 0.05 & $7(3)$ & E0.02 & 0.03 & 01309100 & HAL 600 & CAN 25, USEPA 763 \\
\hline 1,1,2-Trichloro-1,2,2-trifluoroethane/Freon 113 & Freon 113, CFC 113 & 0.05 & $5(2)$ & $\mathrm{N} / \mathrm{A}$ & 0.07 & 01309100 & -- & -- \\
\hline 1,2,3,4-Tetramethylbenzene/Preh-nitene & Preh-nitene & 0.05 & $5(2)$ & N/A & 0.36 & 01393400 & -- & -- \\
\hline 1,2,4-Trichlorobenzene & N/A & 0.2 & $5(2)$ & N/A & 0.02 & 01309100 & MCL 70 & CAN 0.5 \\
\hline 1-Chloro-2-methylbenzene/2-Chlorotoluene & $o$-Chlorotoluene & 0.05 & $5(2)$ & N/A & E0.01 & $\begin{array}{l}01308200 \\
01309100 \\
\end{array}$ & HAL 100 & -- \\
\hline 1-Ethyl-2-methyl-benzene/2-Ethyltoluene & 2-Ethyl toluene & 0.05 & $5(2)$ & N/A & 0.09 & 01393400 & -- & -- \\
\hline Chloroethane & Ethyl chloride & 0.10 & $5(2)$ & N/A & E0.04 & 01367770 & -- & USEPA 230,000 \\
\hline Chloroethene/Vinyl chloride & Vinyl chloride & 0.10 & $5(2)$ & N/A & E0.07 & 01367770 & MCL 2 & -- \\
\hline Chloromethane/Methyl chloride & Methyl chloride & 0.20 & $5(2)$ & N/A & E0.08 & $\begin{array}{l}01464515 \\
01475000\end{array}$ & HAL 3.0 & -- \\
\hline Dichloromethane/Methylene chloride & Methylene chloride & 0.10 & $5(2)$ & N/A & E0.07 & 01309100 & MCL 5.0 & CAN 98 \\
\hline 1,4-Epoxybutane/Tetrahydrofuran & Tetrahydrofuran & 5.00 & $5(2)$ & N/A & E2.8 & 01467329 & -- & - \\
\hline trans-1,2-Dichloroethene & (E)-1,2-Dichloroethene & 0.05 & $5(2)$ & N/A & E0.02 & 01309100 & MCL 100 & -- \\
\hline Trichlorofluoromethane & CFC-11, Freon 11 & 0.10 & $5(2)$ & N/A & 0.53 & 01393400 & HAL 2,000 & -- \\
\hline (1-Methylethyl)benzene/Isopropylbenzene & Cumene & 0.20 & $2(1)$ & N/A & E0.01 & 01393400 & -- & -- \\
\hline (1-Methylpropyl)benzene/sec-Butylbenzene & N/A & 0.05 & $2(1)$ & N/A & E0.03 & 01393400 & -- & -- \\
\hline 1,2,3,5-Tetramethylbenzene/Isodurene & Isodurene & 0.05 & $2(1)$ & N/A & 0.22 & 01393400 & -- & -- \\
\hline 1,2,3-Trichloropropane & Allyl trichloride & 0.20 & $2(1)$ & N/A & E0.11 & 01309100 & HAL 40 & -- \\
\hline 1,2,3-Trimethylbenzene & 1,2,3-Trimethylbenzene & 0.05 & $2(1)$ & N/A & 0.1 & 01393400 & -- & -- \\
\hline 1,3,5-Trimethylbenzene & Mesitylene & 0.05 & $2(1)$ & N/A & 0.09 & 01393400 & -- & -- \\
\hline 1-Isopropyl-4-methylbenzene/p-Isopropyltoluene & $p$-Cymen & 0.05 & $2(1)$ & N/A & E0.04 & 01393400 & -- & -- \\
\hline Bromodichloromethane & Dichlorobromomethane & 0.10 & $2(1)$ & N/A & E0.02 & 01382000 & MCL 100 & -- \\
\hline Dichlorodifluoromethane & CFC-12, Freon-12 & 0.20 & $2(1)$ & N/A & 0.24 & 01308200 & HAL 1,000 & -- \\
\hline Ethenylbenzene/Styrene & Styrene & 0.05 & $2(1)$ & N/A & E0.009 & 01393400 & MCL 100 & -- \\
\hline Ethyl tert-butyl ether/Ethyl-t-butyl ether & ETBE & 0.10 & $2(1)$ & N/A & E0.02 & 01411110 & -- & -- \\
\hline Iodomethane/Methyl iodide & Methyl iodide & 0.05 & $2(1)$ & N/A & E0.02 & 01475000 & -- & -- \\
\hline$n$-Propylbenzene & Isocumene & 0.05 & $2(1)$ & N/A & E0.04 & 01393400 & -- & -- \\
\hline
\end{tabular}


populated and developed areas of the country, VOCs and other toxic chemicals are expected to be present in surface and ground waters. Previous studies of VOCs in surface waters include those by Delzer and others (1996), who reported the frequent detection of VOCs in urban stormwater across the United States, and Terracciano and O'Brien (1997), who examined available data documenting the widespread detection of VOCs in streams on Long Island, New York, and in New Jersey. Sampling for VOCs in the atmosphere and unsaturated zone is also underway as part of a study of toxic compounds in the urban environment in a rapidly developing region of southern New Jersey (A.L. Baehr, U.S. Geological Survey, written commun., 1997).

\section{Sampling for Volatile Organic Compounds}

As part of the LINJ NAWQA program effort to understand the effects of toxic compounds in surface water and bed sediment on aquatic-community health, surface water at 42 stream sites on Long Island and in New Jersey was sampled for VOCs during January 27-30, 1997 (fig. 1). The streams were sampled at this time because concentrations of VOCs in streams are expected to be highest during the coldest months of the year. This fact sheet documents the results of the analysis of these samples and describes the spatial variability of VOCs in streams draining watersheds of different land-use composition.

Samples were collected at the center of flow of each stream with a sampler designed by the USGS for use in the NAWQA program. Shelton (1997) describes the sampler and its use in detail. Samples were acidified with 2 drops of $1: 1 \mathrm{HCl}$ and shipped on ice to the USGS National Water Quality Laboratory (NWQL). The samples were analyzed for 86 VOCs by using a recently approved method for the determination of low concentrations of VOCs in water (D. L. Rose, U.S. Geological Survey, written commun., 1997). VOC

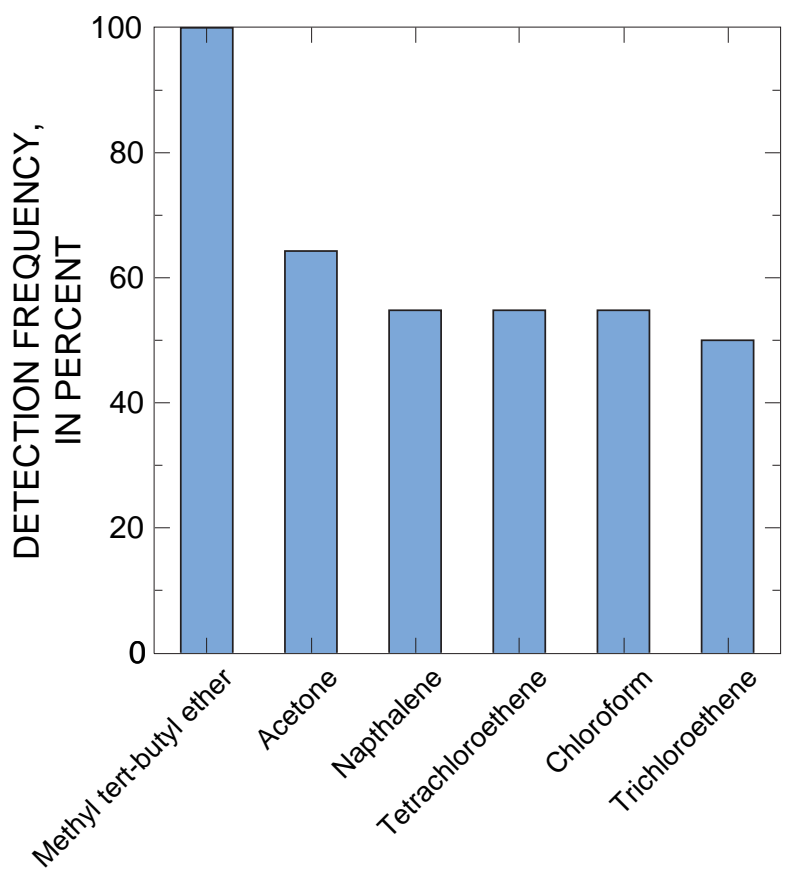

Figure 2. Detection frequency of the most frequently detected volatile organic compounds in 42 samples from streams sampled January 27-30, 1997.
Table 2. Volatile organic compounds analyzed for but not detected in 42 surface-water samples collected from streams on Long Island, New York, and in New Jersey, January 27-30, 1997 [IUPAC, International Union of Pure and Applied Chemistry; NWQL, U.S. Geological Survey National Water Quality Laboratory; NDV, non-detect value; $\mu \mathrm{g} / \mathrm{L}$, micrograms per liter; N/A, not available]

\begin{tabular}{|c|c|c|}
\hline Compound name (IUPAC/NWQL) & Trade name & $\begin{array}{c}\mathrm{NDV} \\
(\mu \mathrm{g} / \mathrm{L})\end{array}$ \\
\hline Vinyl acetate & Vinyl acetate & 0.05 \\
\hline (1,1-Dimethylethyl)benzene/tert-Butylbenzene & N/A & 0.05 \\
\hline 1,1,1,2,2,2-Hexachloroethane/Hexachloroethane & Hexachloroethane & 0.05 \\
\hline 1,1,1,2-Tetrachloroethane & $1,1,1,2-\mathrm{TeCA}$ & 0.05 \\
\hline 1,1,2,2-Tetrachloroethane & $1,1,2,2-\mathrm{TeCA}$ & 0.10 \\
\hline 1,1,2-Trichloroethane & Vinyl trichloride & 0.10 \\
\hline 1,1-Dichloropropene & N/A & 0.05 \\
\hline 1,2,3-Trichlorobenzene & $1,2,3-\mathrm{TCB}$ & 0.20 \\
\hline 1,2-Dibromo-3-chloropropane & DBCP, Nemagon & 0.50 \\
\hline 1,2-Dibromoethane & EDB, Ethylenedichloride & 0.10 \\
\hline 1,2-Dichloroethane & Ethylenedichloride & 0.05 \\
\hline 1,2-Dichloropropane & Propylenedichloride & 0.05 \\
\hline 1,3-Dichloropropane & Trimethylenedichloride & 0.05 \\
\hline 1-Chloro-4-methylbenzene/4-Chlorotoluene & p-Chlorotoluene & 0.05 \\
\hline 2,2-Dichloropropane & N/A & 0.05 \\
\hline 2-Hexanone & 2-Hexanone & 5.00 \\
\hline 2-Propenal/Acrolein & Acrolein & 2.00 \\
\hline 2-Propenenitrile/Acrylonitrile & Acrylonitrile & 2.00 \\
\hline 3-Chloro-1-propene & 3-Chloro-1-propene & 0.10 \\
\hline Bromobenzene & Phenyl bromide & 0.05 \\
\hline Bromochloromethane & Methylene chlorobromide & 0.10 \\
\hline Bromoethene/Vinyl bromide & Vinyl bromide & 0.10 \\
\hline Bromomethane/Methyl bromide & Methyl bromide & 0.10 \\
\hline cis-1,3-Dichloropropene & (z)-1,3-Dichloropropene & 0.10 \\
\hline Dibromochloromethane & Dibromochloromethane & 0.10 \\
\hline Dibromomethane & Methylene dibromide & 0.10 \\
\hline Ethyl methacrylate & Ethyl methacrylate & 1.00 \\
\hline Hexachlorobutadiene & Hexachlorobutadiene & 0.20 \\
\hline Methyl acrylate & Methyl acrylate & 2.00 \\
\hline Methyl acrylonitrile & Methyl acrylonitrile & 2.00 \\
\hline Methyl methacrylate & Methyl methacrylate & 1.00 \\
\hline$n$-Butylbenzene & 1-Phenylbutane & 0.05 \\
\hline Tetrachloromethane/Carbon tetrachloride & Carbon tetrachloride & 0.05 \\
\hline trans-1,3-Dichloropropene & (E)-1,3-Dichloropropene & 0.10 \\
\hline trans-1,4-Dichloro-2-butene & trans-1,4-Dichloro-2-butene & 5.00 \\
\hline Tribromomethane/Bromoform & Bromoform & 0.20 \\
\hline
\end{tabular}

concentrations were determined by purge-and-trap isolation and concentration and capillary-column gas chromatography/mass spectrometry on the basis of methods described in U.S.

Environmental Protection Agency (USEPA) method 524.2, revision 4.0 (U.S. Environmental Protection Agency, 1992), and Rose and Schroeder (1994). The new method includes a larger compound list as a result of minor improvements in instrumental operating conditions, modified quantitation ions, and strategies for reporting data near the method detection levels (D. L. Rose, written commun., 1997). For example, confirmed detections below the non-detect value (NDV) are qualified with an "E" to indicate that accurate quantitation is not guaranteed. 


\section{Volatile Organic Compounds in Streams}

A total of 50 VOCs were detected in water from the 42 sampling sites (table 1). Compounds analyzed for but not detected in any of the 42 samples collected are listed in table 2 . The six most frequently detected VOCs were methyl tert-butyl ether (MTBE), acetone, naphthalene, tetrachloroethene (PCE), chloroform, and trichloroethene (TCE) (fig. 2). MTBE is a fuel oxygenate added to gasoline to enhance combustion and reduce carbon monoxide emissions and ozone in the atmosphere (Squillace and others, 1997). Acetone is used for cleaning and drying purposes and as a solvent in many industries; it is also a natural biodegradation product prior to the formation of organic acids. Naphthalene is a component of fuel oil; PCE is used extensively in dry cleaning and as a solvent in many industries. Chloroform is used as both a raw material and a solvent in industry and is a byproduct of drinking-water chlorination. TCE is used mainly as a metal degreaser, but is also found in dyes, inks, cleaners, and disinfectants.

The maximum measured concentrations of these six VOCs were MTBE, $8.7 \mu \mathrm{g} / \mathrm{L}$ (micrograms per liter); acetone, $6.6 \mu \mathrm{g} / \mathrm{L}$; naphthalene, $0.68 \mu \mathrm{g} / \mathrm{L}$; PCE, $4.6 \mu \mathrm{g} / \mathrm{L}$; chloroform, $0.1 \mu \mathrm{g} / \mathrm{L}$; and TCE, $1.2 \mu \mathrm{g} / \mathrm{L}$, respectively. These concentrations were measured in samples collected at Sampawams Creek, N.Y. (site 2), Santapogue Creek, N.Y. (site 3), or Elizabeth River, N.J. (site 21) (fig. 1). None of the concentrations measured exceeded the USEPA drinking-water maximum contaminant level (MCL) or lifetime health-advisory level (HAL) (table 1). Toxic Release Inventory (TRI) data compiled for the LINJ study area for the six most frequently detected compounds are shown in table 3 (U.S. Environmental Protection Agency, 1994). The TRI is a data base of toxic chemical releases into the environment that was established under the Emergency Planning and Community
Table 3. Toxic Release Inventory data for the six most frequently detected volatile organic compounds in samples collected from 42 streams on Long Island, New York, and in New Jersey (U.S. Envi-ronmental Protection Agency, 1994)

[--, no reported releases]

\begin{tabular}{l|r|r|r|r}
\hline Volatile organic compound & $\begin{array}{c}\text { Release to } \\
\text { water -- } \\
\text { Rank (out of } \\
24 \text { volatile } \\
\text { organic } \\
\text { compounds) }\end{array}$ & $\begin{array}{c}\text { Release } \\
\text { to water } \\
\text { (pounds) }\end{array}$ & $\begin{array}{c}\text { Total } \\
\text { release - } \\
\text { Rank (out of } \\
111 \text { volatile } \\
\text { organic } \\
\text { compounds) }\end{array}$ & $\begin{array}{c}\text { Total } \\
\text { release } \\
\text { (pounds) }\end{array}$ \\
\hline Methyl tert-butyl ether & 7 & 212 & 14 & 150,007 \\
\hline Acetone & 16 & 49 & 1 & $2,852,916$ \\
\hline Naphthalene & 6 & 261 & 37 & 11,707 \\
\hline Chloroform & -- & 0 & 35 & 15,610 \\
\hline Tetrachloroethene & 12 & 94 & 12 & 312,286 \\
\hline Trichloroethene & -- & 8 & 866,175 \\
\hline
\end{tabular}

Right-to-Know Act of 1986 and expanded under the Pollution Prevention Act of 1990 (described in U.S. Environmental Protection Agency, 1994). The six compounds most frequently detected in this study all ranked within the upper third of VOCs listed in order of total releases to the environment.

The number of VOCs detected at each site was examined with respect to the land-use composition of the basin. The number of VOCs detected at a site ranged from 2 to 30 (fig. 3). In general, the number of VOCs detected was highest at sites draining basins with high percentages of urban land use. Relatively high numbers of VOCs were detected in several basins dominated by forested land as well (fig. 3), however, indicating the likely presence of a point source in these basins.

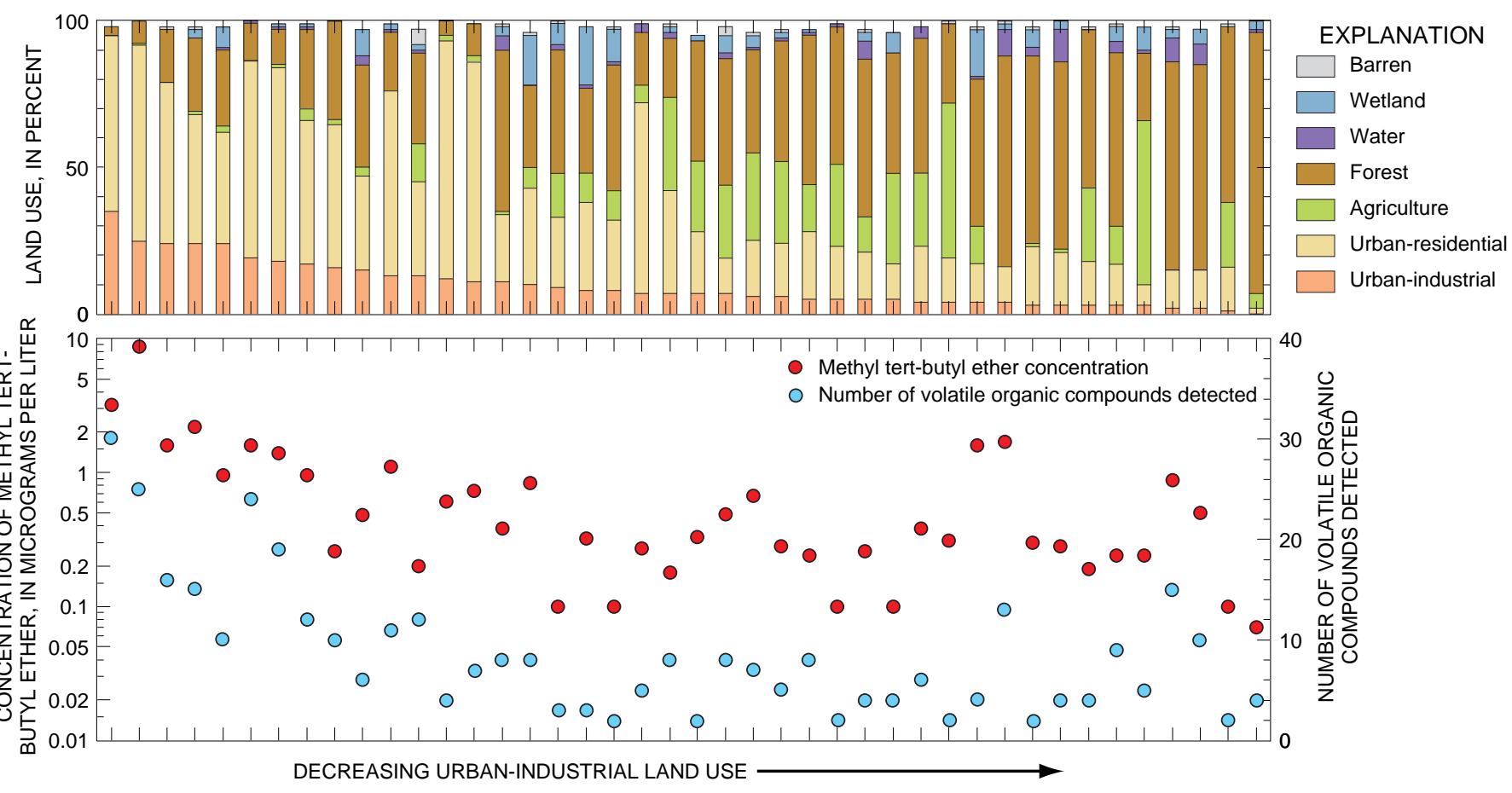

Figure 3. Relation of number of volatile organic compounds detected in stream samples and methyl tert-butyl ether concentrations to land-use composition of drainage basin. 


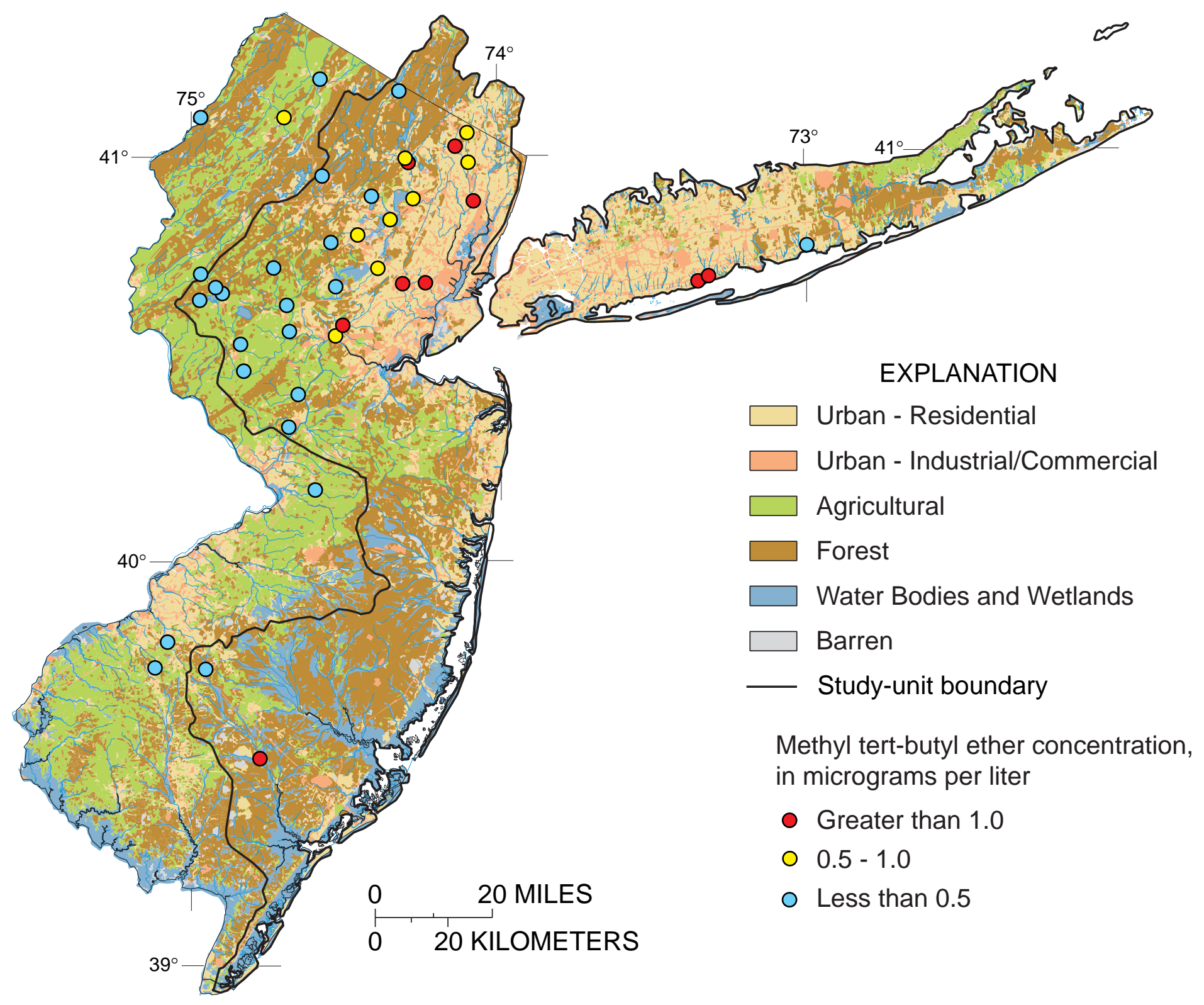

Figure 4. Land use and concentrations of methyl tert-butyl ether at sampling sites.

Because MTBE was the most frequently detected VOC, concentration data for this compound were examined further. With the exception of one site in southern New Jersey, the highest concentrations of MTBE were measured in the most intensively developed parts of the study area (fig. 4), in streams draining basins with the highest percentages of urban land use (fig. 3). A few high concentrations of MTBE, however, were measured at sites draining primarily forested land.

\section{Sources of Contamination}

Direct industrial and wastewater discharges, accidental spills of fuel products or industrial solvents, and urban runoff are the most likely sources of VOCs in surface waters. The high concentrations of VOCs (greater than $1.5 \mu \mathrm{g} / \mathrm{L}$ ) measured in streams draining both urban and undeveloped land are likely attributable to discharges from point sources. All water that contributes to streamflow, however, is susceptible to contamination with VOCs. VOCs in rainfall can originate from vehicle and industrial emissions. The presence of MTBE at low concentrations (less than $1 \mu \mathrm{g} / \mathrm{L}$ ) in streamwater may be a result of equilibration with similar concentrations of this compound in the atmosphere (Squillace and others, 1996). Runoff from streets and impervious surfaces is another source of VOCs in streams (Delzer and others, 1996). Leaky storage tanks, spills, improper disposal of chemicals, and septic systems may be direct sources of VOC contamination to ground water, which eventually supplies base flow to streams. 


\section{Summary and Conclusions}

This study documents the frequent occurrence of VOCs, particularly MTBE, in streams draining basins with all types of land use on Long Island, N.Y., and in New Jersey. VOCs were detected in water from all 42 sampling sites on Long Island and in New Jersey during January 27-30, 1997. The concentrations of VOCs were higher and more compounds were detected in streams draining more developed basins. Concentrations of all of the VOCs detected, however, were below existing water-quality criteria.

Evaluation of these data with respect to human and aquatic health is difficult for several reasons. MCLs, HALs, and criteria for aquatic organisms have been established for only a few of the VOCs detected. Futhermore, MCLs and HALs apply to individual compounds; however, most samples contained more than one compound. The potential cumulative or synergistic effects of the presence of multiple compounds is unknown.

---Anne K. O'Brien, Robert G. Reiser, and Helle Gylling

\section{References Cited}

Bloeman, H.J.Th., and Burn, J., 1993, Chemistry and analysis of volatile organic compounds in the environment: New York, Blackie Academic and Professional, 290 p.

Canadian Council of Resource and Environment Ministers, 1991, Canadian water quality guidelines: Ottawa, Ontario, Environment Canada, Inland Waters Directorate, Water Quality Branch (updated May 1996), variously paged.

Delzer, G.C., Zogorski, J.S., Lopes, T.J., and Bosshart, R.L., 1996, Occurrence of the gasoline oxygenate MTBE and BTEX compounds in urban stormwater in the United States, 1991-95: U.S. Geological Survey Water-Resources Investigations Report 96-4145, 6 p.

Rose, D.L., and Schroeder, M.P., 1994, Methods of analyses by the U.S. Geological Survey National Water-Quality Laboratory--Determination of volatile organic compounds in purge and trap capillary gas chromatography/mass spectrometry: U.S. Geological Survey Open-File Report 94-708, $26 \mathrm{p}$.

Schwarzenbach, R.P., Gschwend, P.M., and Imboden, D.M., 1993, Environmental organic chemistry: New York, John Wiley and Sons, Inc., $681 \mathrm{p}$.
Shelton, L.R., 1997, Field guide for collecting samples for analysis of volatile organic compounds in stream water for the National Water-Quality Assessment program: U.S. Geological Survey Open-File Report 97-401, 14 p.

Squillace, P.J., Pankow, J.F., Korte, N.E., and Zogorski, J.S., 1997, Review of the environmental behavior and fate of MTBE: Journal of Environmental Toxicology and Chemistry, v. 16, no. 9, p. 1836-1844.

Squillace, P.J., Zogorski, J.S., Wilber, W.G., and Price, C.V., 1996, Preliminary assessment of the occurrence and possible sources of MTBE in groundwater in the United States, 1993-1994: Environmental Science \& Technology, v. 30, no. 5, p. 1721-1730.

Terracciano, S.A., and O'Brien, A.K., 1997, Occurrence and distribution of VOCs in streams on Long Island, New York, and in New Jersey--A review of existing and reconnaissance data: U.S. Geological Survey Fact Sheet FS-063-97, 4 p.

U.S. Environmental Protection Agency, 1992, Measurement of purgeable organic compounds in water by capillarycolumn gas chromatography/mass spectrometry, method 524.2, revision 4.0: Cincinnati, Ohio, Environmental Monitoring Systems Laboratory, August 1992, 50 p. 1994,Toxics release inventory public data release: Washington, D.C., Office of Pollution Prevention and Toxics, EPA 745-R-94-001, 288 p. 1995, Guidance for assessing chemical contaminant data for use in fish advisories: Volume 1, Fish sampling and analysis, $2 \mathrm{~d}$ ed.: Washington, D.C., Office of Water, EPA 823-R-95-007, 289 p. plus appendixes. 1996, Drinking water regulations and health advisories: Washington, D.C., Office of Water, EPA 822-B-96-002, $16 \mathrm{p}$.

Information about the NAWQA program can be obtained from:

NAWQA Project Chief

U.S. Geological Survey

Mountain View Office Park

810 Bear Tavern Road, Suite 206

West Trenton, NJ 08628 